\title{
La CoRte Suprema como TITULAR DE PODER REGLAMENTARIO'
}

\section{Estela Sacristán}

\author{
Universidad Austral
}

es@bgcv.com.ar

Recibido: $4 / 11 / 2020$

Aceptado: $18 / 11 / 2020$

\section{Resumen}

Durante 2020, en medio de la pandemia originada por el virus COVID-19, se ha generado una preocupación de la rama ejecutiva de gobierno por la detección de problemas de funcionamiento en la Corte Suprema de Justicia de la Nación argentina. Ello podría propiciar iniciativas legislativas acordes. Empero, estimamos que la propia competencia reglamentaria de ese Tribunal basta para llevar a cabo las tareas de autodiagnóstico e implementación de soluciones enderezadas a sobrellevar muchos de los problemas que pueden visualizarse en el trabajo interno de la Corte Suprema. A los fines de sustentar la propuesta, en el presente artículo se indaga en las fuentes de rango constitucional e infraconstitucional de la mencionada potestad, a los fines de delinearla, fijar sus limitaciones y precisar, en el caso de estas últimas, sus dos vertientes delegantes posibles: (i) leyes que establezcan estructuras y sus competencias; y (ii) leyes que fijen los procedimientos. A partir de allí, se repara en la experiencia comparada y se propician las conclusiones finales.

Palabras clave: Corte Suprema de Justicia de la Nación, potestad reglamentaria, delegación.

\section{The Supreme Court as Rule Maker}

\begin{abstract}
During 2020, amidst the pandemic, there has arisen, in the executive branch of government, a concern regarding the detection of problems in the functioning of the Argentine Supreme

1 Se agradecen los valiosos comentarios del Dr. Alberto F. Garay, recibidos en la etapa de elaboración del presente artículo, así como los datos aportados por la Dra. Silvia Palacio de Caeiro y del Dr. Andrés Ascárate. Son aplicables las reservas usuales.
\end{abstract}


Court of Justice. This scene could give rise to the corresponding legislative action. Nevertheless, the Tribunals rulemaking power itself can be deemed sufficient to fulfill the tasks of self-diagnosis and implementation of solutions aimed at overcoming many of the problems that can be ascertained in the Supreme Court internal work. In order to justify the proposal, this paper enquires into the constitutional and infra-constitutional sources of the Supreme Court's regulatory power, in order to delineate it, establish its limitations and ascertain, in the case of the infra-constitutional sources, their two possible delegating paths: (i) laws that establish structures and their competences, and (ii) laws that establish procedures. From then on, the comparative experience is reviewed, and the final conclusions are drafted.

Key words: Argentine Supreme Court of Justice, rule-making power, delegation.

\section{Planteo}

La oportunidad no pudo ser más llamativa. En medio de la pandemia originada por el virus COVID-19, las tomas de tierras, la publificación de actividades privadas por decreto, el drenaje de reservas del Banco Central y los incendios en diversas provincias argentinas, 2020 nos ha traído un plan impulsado desde el Poder Ejecutivo nacional. Este, en lo que aquí interesa, se halla volcado en el Decreto 635/2020, ${ }^{2}$ dictado bajo el artículo 99, inciso 1 de la Constitución Nacional $(\mathrm{CN})$ como reglamento autónomo, y apunta al fortalecimiento del Poder Judicial.

De cara a ese elevado objetivo, podemos preguntarnos si no resulta más eficaz, eficiente y ético no un fortalecimiento impulsado externamente desde los poderes políticos, sino uno generado desde dentro de la rama judicial de gobierno. Específicamente, uno impulsado y concretado desde la máxima autoridad de la pirámide jerárquica de la Justicia federal.

En el marco de los objetivos del Decreto 635/2020, se destaca la labor de indicar "los problemas que se observan para el correcto funcionamiento" 3 de, entre otros órganos, la Corte Suprema de Justicia de la Nación. Pues bien, esa identificación de problemas, junto con la regulación de los medios para superarlos en la faz de "funcionamiento", puede llevarse a cabo mediante la herramienta históricamente más consolidada en todo órgano estatal y en la Corte Suprema en particular: la potestad reglamentaria.

2 Decreto 635/2020, BO 30/07/2020, creación del Consejo Consultivo para el Fortalecimiento del Poder Judical y del Ministerio Público.

3 Decreto 635/2020, artículo 4, inciso 1: "Descripción valorativa con especial indicación de los problemas que se observan para el correcto funcionamiento de la Corte Suprema de Justicia de la Nación [...]". 
Así las cosas, el Alto Tribunal mismo podría llevar adelante su autoevaluación, con identificación de problemas detectables en su funcionamiento (aunque a fuer de claridad no es una máquina), y podría sancionar las reglamentaciones o regulaciones adecuadas para dejarlos atrás. Ya lo ha hecho antes, y cito un ejemplo de trascendencia especialmente profesional, como la acordada sobre recurso extraordinario, ${ }^{4}$ la cual, entiendo, respondió en parte a las dificultades que presentaba el análisis de recursos extraordinarios necesitados de normalización en sus aspectos neurales y de especificidad de cara al caso en concreto. Es que, en rigor, nadie sabe más acerca del funcionamiento de la Corte Suprema que la Corte Suprema misma; ${ }^{5}$ en dicha escena, nadie mejor que ella para autodiagnosticarse, detectar problemas y enderezarlos con alcance general. Se trata del ejercicio de una competencia que ha llevado a cabo desde antaño: ya en 1863 dictó su reglamento para el orden interior, ${ }^{6}$ y en 1865 ponderó el cúmulo de asuntos a despachar y decidió, por acuerdo, cumplir asistencia en el Tribunal los martes, jueves y sábados. ${ }^{7}$ Ello demuestra que, desde sus orígenes, la Corte Suprema ha sabido, cuando lo entiende oportuno, volcar su mirada hacia sí misma a los fines de adoptar decisiones de alcance general tendientes a perfeccionar su desenvolvimiento.

El ejercicio de la potestad reglamentaria por parte de la Corte Suprema, empero, no puede tomarse por sentado o presupuesto, más allá de que resulte inherente a todo órgano estatal. Antes bien, la acometida metodológica de la cuestión obliga a inquirir, al menos, en aspectos relativos a las fuentes de esa potestad (sección 2.) y la experiencia comparada, especialmente emanada de la Suprema Corte estadounidense, que la nutre (sección 3.); ambas líneas de análisis suscitan interrogantes que serán oportunamente encarados y respondidos, siquiera en forma liminar. A tales fines, entonces, se dedican estos párrafos.

Valga aclarar que a lo largo del presente trabajo, la expresión "potestad reglamentaria" se empleará en el sentido ya admitido por la doctrina como actividad reglamentaria o de emisión de reglamentos o actos de alcance general, en este caso, del específico órgano judicial involucrado. Como actividad reglamenta-

4 Acordada 4/2007, BO 21/03/2007, del 21/3/2007. Las acordadas y resoluciones citadas en el presente que no tengan datos de publicación en colecciones oficiales o privadas se hallan disponibles en: https://www.csjn.gov.ar/sentencias-acordadas-y-resoluciones/acordadas-de-la-corte-suprema.

5 En igual sentido, ver Bianchi (1990, pp. 231-232).

6 Reglamento para el Orden Interior de la Suprema Corte y Organización de sus Oficinas, publicado en Fallos: 1:7, del 11/10/1863.

7 Acordada s.n., publicada en Fallos: 2:6, del 7/07/1865. 
ria será una actividad no jurisdiccional, "no judicial”, ejercida por el órgano judicial (Bidart Campos, 1993, p. 417), que se caracteriza por ser de sustancia "normativa o legislativa" (Cassagne, 2018, pp. 59-60). En tanto potestad, será un "reflejo cualificado" del poder (Marienhoff, 1990, p. 604), del cual tiene que ser distinguida. En suma, se trata de un poder cualificado, pacíficamente admitido por la doctrina en cuanto a su localización no solo en las ramas ejecutiva y legislativa, sino también en la judicial (Cassagne, 2018, p. 60; Gordillo, 2009, p. VII-42; Marienhoff, 1990, p. 240), manifestación de una actividad no judicial enderezada al dictado de medidas de alcance general que podemos -en forma genérica- denominar "reglamentos judiciales". ${ }^{8}$ Estos materializarán regulaciones de la más variada índole. ${ }^{9}$ Por ende, se excluye del presente trabajo el estudio de aquellas decisiones que, bajo un ropaje de decisión no jurisdiccional, de alcance general, trasunten el ejercicio de potestad jurisdiccional-judicial, en especial el ejercicio del control de constitucionalidad. ${ }^{10}$

\section{Fuentes de la potestad reglamentaria de la Corte Suprema}

La potestad reglamentaria de la Corte Suprema de Justicia de la Nación halla pluralidad de fuentes. Entre ellas, cabe resaltar las de rango constitucional y las de rango infraconstitucional. Como enseguida veremos, las primeras giran en torno al artículo 113 de la CN. En cambio, las fuentes de rango infraconstitu-

8 Ampliar en Bidart Campos (1997, p. 243); Cassagne (2020, p. 305); Marienhoff (1990, pp. 240-241 y p. 244).

9 En la disidencia del juez Rosatti como conjuez en Gutiérrez, Oscar Eduardo c/ANSeS, Fallos: 329:1092, del $11 / 4 / 2006$, considerando $13^{\circ}$ se enumeran las materias "administrativa, organizacional y de superintendencia". Podría parecer arduo diferenciarlas, especialmente dada la amplitud del término "administrativo", que parece comprender a las restantes. Ver, empero, las diferenciaciones que se harán más adelante, en el apartado 2.2.

10 Como ser la involucrada en Gutiérrez, Oscar Eduardo c/ANSeS, Fallos: 329:1092, del 11/04/2006. Aun cuando en dicho fallo se afirma que la Acordada 20/1996, de Fallos: 319:24, es un "proveimiento administrativo de carácter general emanado de la Corte Suprema" (considerando 9॰ del voto de la mayoría), cabe recordar que en esa acordada se declaró inaplicable una norma.

La única forma de que se inaplique una norma aplicable a un caso es declararla inconstitucional, de modo tal que se pueda prescindir de ella como si no existiera (doctrina Gregolinsky y Cía, Fallos: 202:184, del 16/7/1945, conforme la cual, declarada inconstitucional una norma, las cuestiones planteadas deben ser resueltas como si aquella no existiera). La inaplicación -sin que mediara petición alguna- resuelta en la Acordada 20/1996, entonces, fue concreción de actividad materialmente jurisdiccional-judicial (que permite el ejercicio del control de constitucionalidad por parte del órgano judicial) y no fue materialización de potestad reglamentaria. Ampliar, con provecho, en Sáenz (2008, pp. 27-28). Sobre las relaciones género y especie entre lo jurisdiccional y lo judicial, se sigue a Badeni (2010, p. 697) y sus citas de Luqui (2005, pp-21-22). 
cional de esa potestad reglamentaria ponen en juego al artículo 75, inciso 20 y a los artículos 116 y 117 de la CN.

Huelga apuntar que, en este marco, el ejercicio de la potestad reglamentaria emergente del artículo 113 de la $\mathrm{CN}$ no requerirá ley previa y será ejercible autónomamente, como cuando se dicta un reglamento autónomo del artículo 99, inciso 1 de la CN. Por el contrario, el ejercicio de la competencia reglamentaria habilitada por los artículos 75, inciso 20, y 116 y 117 de la CN siempre requerirá ley previa, pues la Constitución no efectúa asignación directa de competencia a favor de la Corte Suprema y dará lugar al dictado de un reglamento que -según el punto de vista que se adopte- podrá ser un reglamento delegado o un reglamento de ejecución de las leyes. Veamos lo relativo al artículo 113 de la CN (sección a), para luego centrarnos en los artículos 75, inciso 20, y 116 y 117 de la CN (sección b).

\subsection{Rango constitucional. Habilitación para el dictado de reglamentos autónomos emanados de la Corte Suprema}

La Constitución de 1853 estableció, en su artículo 99, que "La Corte Suprema dictará su reglamento interior y económico, y nombrará todos sus empleados subalternos". A su turno, la Constitución de 1949, que rigió hasta 1956, previó, en su artículo 94, que "La Corte Suprema de Justicia dictará su reglamento interno y económico, y nombrará sus empleados”. Entre 1956 y 1994 rigió el texto ya transcripto de la Constitución de 1853. La Constitución reformada en 1994 establece, en su artículo 113, que "La Corte Suprema dictará su reglamento interior y nombrará a sus empleados".

De estas redacciones se infiere la continua preocupación del Constituyente por que el Tribunal cuente con potestad reglamentaria a los fines de autorregularse internamente. También puede inferirse la superación de textos constitucionales anteriores insuficientes, tales como el de la Constitución de 1819 (artículo 96) o el de la de 1826 (artículo 117), que preveían tan solo que el máximo Tribunal podía nombrar a sus "oficiales". Adviértase, empero, que Seco Villalba (1943, p. 223) halla -en dicho artículo 117- el antecedente nacional del artículo 99 -actual artículo 113- de la Constitución Nacional. ${ }^{11}$

En términos generales, la admisión de esta potestad reglamentaria, en cabeza del máximo Tribunal, representa la superación de la tesis negativa, que

11 El artículo 117 de la Constitución de 1826 establecía: "La alta corte de justicia nombrará sus oficiales, en el número y forma, que prevenga la ley”. 
hallara manifestación en el Proyecto de Constitución de 1813 (Seco Villalba, 1943, p. 262). ${ }^{12}$

\subsubsection{Caracteres}

De acuerdo con lo expresado precedentemente, se trata de una competencia de fuente textual constitucional, de carácter privativo, que el Constituyente le asignó expresa y directamente a la Corte Suprema de Justicia de la Nación.

Además, no involucra ejercicio de competencia jurisdiccional o judicial alguna por parte del Alto Tribunal, sino el ejercicio de una de tenor normativo o legislativo, entiendo, por manifestarse en decisiones de "carácter general". ${ }^{13}$ Estas decisiones de alcance general, a su vez, han sido consideradas como de naturaleza de reglamento administrativo, ${ }^{14}$ las cuales trasuntarán, al menos, el empleo de atribuciones de tipo administrativo en el sentido de excluyentes de atribuciones de tipo jurisdiccional (Bianchi, 1986, p. 181).

\subsection{2. ¿Reconocimiento o "delegación" en la Corte Suprema por parte del Constituyente?}

A tenor de la literalidad del artículo 113 de la $\mathrm{CN}$, puede decirse que se configura un poder que puede ser apreciado tanto como: (i) un reconocimiento, por parte del Constituyente, de una potestad propia de la Corte Suprema; y (ii) una "delegación del Constituyente" a favor del Alto Tribunal.

Avala la primera posibilidad interpretativa el lenguaje de la cláusula constitucional, pues no se emplea el verbo "delégase", "facúltase" u otro similar, sino que, derechamente, se afirma que ese Tribunal "dictará" ese reglamento interno.

Sostiene la segunda interpretación el acoger la tesis del primer acto de delegación, efectuado por las provincias a favor del Constituyente en $1853^{15} \mathrm{y}$, en ese marco, concebir una suerte de continuum de poder, por el cual el Constituyente (delegatario de las provincias) delega, a su vez, en el órgano máximo de

12 El artículo 137 del Proyecto de Constitución para las Provincias Unidas del Río de la Plata, del 27/01/1813, proponía: "Los Tribunales no pueden formar Reglamentos para la administración de justicia ni ejercer otras funciones que las judiciales".

13 En similar sentido, ver Bianchi (1986, p. 181).

14 Considerándolas reglamentos administrativos, ver Bianchi (2014, p. 1214).

15 Acerca del primer acto de delegación de las provincias a favor del Constituyente ampliar en Bianchi (1990, p. 19). 
un poder constituido -como el Poder Judicial (delegatario de rango constitucional, si se quiere) - determinada potestad (en la especie, la potestad reglamentaria del artículo 113 de la $\mathrm{CN}$ ).

Desde un punto de vista de legitimidad democrática, entiendo que esta segunda interpretación es la más acorde con el artículo 1 de la CN. Sin embargo, advierto igualmente que cualquiera sea la interpretación que se adopte, no se modifican los razonamientos que siguen.

\subsubsection{Alcances de la expresión "reglamento interno" en el artículo 113}

Una interpretación restrictiva del artículo 113 de la CN permitiría afirmar que la Corte Suprema debería limitar su potestad reglamentaria fundada en ese artículo al dictado de sus reglamentaciones internas. Por el contrario, una interpretación amplia permitirá que regle otras cuestiones bajo el rótulo de que se trata de una "reglamentación interna". ¿Puede acogerse la posibilidad de interpretación amplia?

En principio, puede afirmarse que todo órgano u ente estatal tiene competencia "materialmente" administrativa, jurisdiccional y normativa (Cabral, 1986, pp. 184-185; Cassagne, 2018, p. 57; Marienhoff, 1990, p. 77), y la competencia normativa -o legislativa o reguladora- bien puede manifestarse en el dictado de reglamentos emanados de la Corte Suprema. ${ }^{16}$ Los ejemplos pueden comprender desde un reglamento de contrataciones ${ }^{17}$ hasta la regulación del acceso a las sentencias de, en la especie, la Corte Suprema. ${ }^{18}$ Se tratará de regla-

16 Calificándola como legislativa, ver Bianchi (1986, pp. 181-183). El autor considera que la competencia materialmente legislativa es administrativa en contraposición a materialmente jurisdiccional (p. 182).

17 Ver la Resolución 1562/2000 de la Corte Suprema de Justicia de la Nación, del 21/09/2000, La Ley, Buenos Aires: Thomson Reuters, cita online AR/LEGI/53HH.

18 Ver la Acordada 15/2013, del 21/05/2013, que dispone que las cámaras federales o nacionales y los tribunales orales publicarán todas las sentencias, acordadas y resoluciones administrativas en el Centro de Información Judicial. Ver, asimismo, la Acordada 24/2013, del 21/08/2013, la cual, entre otros aspectos, (i) dispone que, respecto de las sentencias, las cámaras federales y nacionales y los tribunales orales darán cumplimiento a la Acordada 15/2013 mediante el Sistema Informático de Gestión Judicial (en la medida en la que se encuentre implementado) o mediante un protocolo que la propia acordada fija (hasta tanto sea puesto en marcha dicho Sistema); y (ii) declara inaplicable el artículo 4 de la Ley 26856 (que estableció que "Las cuestiones a dirimir en los acuerdos y reuniones que lleve a cabo la Corte Suprema de Justicia de la Nación, que tengan por objeto el dictado de sentencias, acordadas o resoluciones, deberán ser publicadas en el diario judicial con antelación mínima de cinco (5) días de la fecha de la reunión que corresponda" en tanto ello "invade una esfera propia y exclusiva” del Tribunal bajo los artículos 108 y 113 de la CN (considerando $10^{\circ}$ ). Se volverá sobre esta cuestión infra. 
mentos enderezados a que los cuadros internos del Tribunal estén bajo el deber de hacer algo (llamar a licitación, cargar y hacer visibles las sentencias en el sitio web respectivo); y ese deber de hacer algo redundará en eventuales beneficios a terceros (firmas que deseen ofertar, ciudadanía interesada en acceder al contenido de esas sentencias).

La manda del actual artículo 113 de la $\mathrm{CN}$, que, como vimos y con variaciones menores, data de 1853, no halla simetría en la Constitución estadounidense. Esta es la razón por la cual, para el lapso previo a la Rules Enabling Act de 1934 (y sin perjuicio de la Judiciary Act de 1789), se acepta que los tribunales, en la tradición anglo-norteamericana, poseían poderes inherentes para emitir reglas sin previa habilitación congresional (Meador, 1995, p. 1806). ${ }^{19}$ La inclusión del artículo 113 por parte del Constituyente argentino tiene que haber sido ineludible o al menos necesaria. Esa inclusión, empero, no propicia -entiendo- la posibilidad de una interpretación amplia de la expresión "reglamento interno". Se tratará siempre de regulaciones que trasuntarán competencia reglamentaria autónoma no dependiente de una ley previa por emanar directamente del artículo 113, enderezada en primer lugar al plano interorgánico (sin perjuicio de los efectos hacia terceros). Son reglas que la Corte Suprema dicta "para su régimen" ${ }^{20}$ La escena es similar a la generada por el artículo 99, inciso 1 de la CN en relación con el Poder Ejecutivo. Sin embargo, tiene que puntualizarse que el artículo 113 no se agota con el dictado de "un" reglamento interno, sino que podrá haber, en la vida del Tribunal, la sanción, de tanto en tanto, de diversas reglamentaciones internas fundadas en el artículo 113, sea para modificar las existentes, sea para ampliarlas, derogarlas o substituirlas, entre otros supuestos.

19 Meador (1995, p. 1806) afirma que se ha reconocido, desde antaño en Inglaterra, que un tribunal posee poder inherente para prescribir reglas generales de práctica y procedimiento para gobernar la conducción de los casos sobre los cuales tiene jurisdicción. Estados Unidos heredó, de los tribunales ingleses, el concepto de poder inherente de un tribunal sobre su proceso y procedimiento ("It has also long been recognized in England that a court has inherent authority to prescribe general rules of practice and procedure to govern the conduct of cases over which it has jurisdiction. [...] The United States inherited the concept of a court's inherent authority over its process and procedure from the English courts").

20 Robirosa, Antonio c/Iriondo, Petrona C. de, Fallos: 78:281, del 29/04/1899, considerando 2. Esta es una importante competencia que la Corte Suprema posee para reglamentar "hacia adentro de sí misma", como claramente lo expone Gelli (2008, p. 477). 


\subsubsection{Naturaleza}

En este acápite consideremos la Acordada sin número, Reglamento para la Justicia Nacional, ${ }^{21}$ de 1952, artículo 103: "La Corte Suprema tendrá, además, las oficinas y el personal que establezca en su reglamento interno y económico".

Como ha apuntado la doctrina, esa acordada sin número es un reglamento autónomo de la Justicia, pues "trata sobre materias internas del desenvolvimiento de los tribunales y de la actuación ante ellos” (Bianchi, 1990, pp. 232), como ser días hábiles, horarios y feria, entre otros aspectos.

Como reglamento autónomo no requiere actividad previa alguna del Legislador para ser dictado; su materialización corresponde al ejercicio de facultades propias del Tribunal no solo expresas, sino también implícitas o inherentes ${ }^{22}$ a su función específica (Bianchi, 1990, pp. 232), e involucra potestad de fuente directamente constitucional, v.gr., el artículo 113 de la CN.

\subsubsection{Limitaciones}

¿Será el ejercicio de competencia reglamentaria para dictar reglamentos autónomos o de organización interna bajo el artículo 113 de la $\mathrm{CN}$ pasible de limitaciones? Entiendo que sí, de modo tal que el reglamento interno dictado bajo el artículo 113: (i) versará sobre cuestiones no reservadas al Legislador especialmente en los artículos 116 y 117 y 75, inciso 20, de la CN; y (ii) en principio, si con posterioridad a la generación del reglamento autónomo se sancionara una ley con coincidencia de cuestiones reguladas respecto a aquel, el reglamento no podría contradecirla, salvo que haya mediado un exceso o incluso imprevisión del Legislador. La experiencia ayuda a ilustrar estas afirmaciones.

Cuando se dictó la Ley 27275 de Acceso a la Información Pública, ${ }^{23}$ en 2016, ya desde antes la Corte Suprema había reglado aspectos propios del acceso, por parte de terceros, a la información emanada del máximo Tribunal, y lo había hecho mediante reglamentos de tenor interno que, ulteriormente, beneficiaban a los terceros integrantes del público. Lo había hecho en el seno

21 Acordada s.n., Reglamento para la Justicia Nacional, del 17/12/1952, BO 22/04/1953, publicada en Fallos: 224:575.

22 Ver Acordada 4/2000, Fallos: 323:1293, del 14/03/2000, considerando 3o ("Que mediante el ejercicio de los aludidos poderes, connaturales e irrenunciables, este Tribunal ha salvaguardado la independencia del Poder Judicial frente a diversas situaciones que la afectaban [...]" y considerando 9० ("Que la reforma constitucional de 1994 mantiene la atribución de la Corte de dictar su reglamento interior y nombrar a sus empleados (artículo 113)").

23 Ley 27275 de Derecho de Acceso a la Información Pública, BO 29/09/2016. 
del Alto Tribunal, al igual que el Decreto 1172/200324 había reglado el acceso a la información emanada de los cuadros de la Administración Pública Centralizada y Descentralizada. Las medidas de la Corte Suprema para el acceso a la información por ella generada comprendieron la divulgación de los fallos de la Corte Suprema, ${ }^{25}$ la fijación de fecha de acuerdo para las causas de trascendencia institucional ${ }^{26}$ y la publicidad de los registros de circulación de los expedientes ${ }^{27}$ entre otros aspectos. En el supuesto reseñado, fueron reglamentos internos los que dispusieron la puesta a disposición de esa información, si bien no podrían negarse los beneficios hacia terceros, amén de que la citada ley creó el "derecho subjetivo" a accederla, dentro de las condiciones que la propia ley fija en su artículo 8. La citada ley creó el deber, en su artículo 32, inciso h), de publicar "las actas en las que constara la deliberación de un cuerpo colegiado", lo que condujo a preguntarse si era un nuevo deber para la Corte Suprema o si se trataba de un exceso del Legislador que invadía el ámbito del artículo 113 de la CN. La respuesta surge de la Acordada 42/2017, ${ }^{28}$ que regló ese aspecto disponiendo que se cumple aquel recaudo legal con la "notificación y publicación en la página de internet del Tribunal de las decisiones adoptadas en los acuerdos [...]".

Además, en su momento, la Ley 26856, ${ }^{29}$ de 2013, en su artículo 1, ordenó la publicación de todas las sentencias de la Corte Suprema -entre otros tribunales-, sin advertir que ello ya se cumplía desde antes, como vimos. Además, dicha ley, en su artículo 4, ordenó publicar con una antelación mínima de cinco días "las cuestiones a dirimir en los acuerdos" de la Corte Suprema. Esta, por la Acordada 42/2017, ${ }^{30}$ artículo 6, inciso a) dispuso por mayoría que se cumpliría esa manda legislativa: (i) publicando cada acuerdo celebrado; y (ii) mediante el acceso, por parte del solicitante, a los expedientes. En cambio, el Dr. Rosatti -en disidencia- propició, con agudo criterio, que se regulara el

24 Decreto 1172/2003, BO 4/12/2003, Anexo VII.

25 Acordada 37/2003, Fallos: 326:5047, del 18/12/2003.

26 Acordada 36/2003, Fallos: 326:5046, del 18/12/2003.

27 Acordada 35/2003, Fallos: 326:5041, del 11/12/2003.

28 Acordada 42/2017, del 27/12/2017.

29 Ley 26856, BO 23/05/2013, de publicación íntegra de acordadas y resoluciones. Su artículo 4 establece: "Las cuestiones a dirimir en los acuerdos y reuniones que lleve a cabo la Corte Suprema de Justicia de la Nación, que tengan por objeto el dictado de sentencias, acordadas o resoluciones, deberán ser publicadas en el diario judicial con antelación mínima de cinco (5) días de la fecha de la reunión que corresponda".

Acordada 42/2017, del 27/12/2017. 
específico aspecto mediante la indicación -bajo forma de registro en el sistema de gestión Lex 100, accesible por las partes- de que el expediente se halla en condiciones de ser llevado al acuerdo.

Más allá de lo sana y adecuada que resulta la disidencia reseñada de cara a la previsibilidad a nivel de las partes, se advierte en torno a la redacción del artículo 4 de la Ley 26856 que el Legislador no mandó a publicar con cinco días de antelación el nombre de la causa a ser fallada, sino que aspiraba a que se publicaran "las cuestiones a dirimir" en el acuerdo con cinco días de anticipación. Esta manda legislativa resulta llamativa, pues los jueces no dirimen "cuestiones", sino que fallan "casos o controversias". Además, mandar a publicar las "cuestiones a dirimir" no se condice con el modelo de la Suprema Corte estadounidense, que no publica cuáles son las "cuestiones a dirimir", sino que hace públicos, en su web, la enumeración de casos concedidos solo mediante inclusión del nombre de la parte apelante y el de la parte apelada, ${ }^{31}$ sin referencia alguna a la cuestión a dirimir.

Esta segunda experiencia en torno a la Ley 26856, de 2013, pone en evidencia no ya un avance del Legislador, sino su imprevisión, pues incluyó objetos a publicar que ya se hallaban bajo el deber de ser publicados desde años ha (artículo 1, en lo relativo a sentencias de la Corte Suprema) y avanzó sobre la potestad reglamentaria autónoma de la Corte Suprema al mandarla a publicar las "cuestiones a dirimir" cuando ello no se condice ni con la realidad ni con la experiencia comparada que históricamente se ha empleado como referente y que enseña sobre la publicación de causas -recursos concedidos, que serán argumentados oralmente ante el pleno del Tribunal- mediante identificación de las partes.

\subsubsection{Efectos}

El ejercicio de la competencia reglamentaria de tipo autónoma como la aquí descripta posee la virtualidad de poder redundar en la pirámide de la Justicia federal, en delegación intrajudicial, interorgánica, por parte de la Corte Suprema a favor de las Cámaras federales ${ }^{32}$ o, en su caso, a favor del Consejo de la Magistratura. $^{33}$

31 Puede verse un ejemplo para 2020 en Suprema Corte de los Estados Unidos (2020).

32 Corte Suprema de Justicia de la Nación, Guardia, Carlos Eduardo y otra, Fallos: 307:1466, del 22/08/1985, considerando $11^{\circ}$, con cita de la Acordada 65/1984, del 23/10/1984. Un ejempo puede verse en: Acordada 20/1981, Fallos: 302:25, del 25/06/1981.

33 Ver Acordada 11/2004, del 25/03/2004, título y artículo 1; Acordada 26/2007, del 25/10/2007, artículo II. 
A modo de ejemplo, bajo el Reglamento para la Justicia Nacional, la Corte Suprema delega a las cámaras y juzgados el registro de empleados y funcionarios. ${ }^{34}$ Es una delegación interorgánica, intrajudicial, que posee un similar -aunque no identidad- en la pirámide jerárquica de la Administración pública y en el seno de los entes descentralizados de esta última.

\subsubsection{Síntesis parcial}

En conclusión, corrobora el encuadre de "reglamento interno" aquí adoptado -en cuanto a las tres acordadas reseñadas- la propia Acordada 42/2017,,$^{35}$ que invoca las facultades emergentes del artículo 113 de la CN. Esa fuente directamente constitucional habilita el ejercicio de competencia reglamentaria autónoma, que no requiere ley habilitante previa. Dentro del ámbito que crea el artículo 113, son variadas las reglamentaciones internas que la Corte Suprema, en forma autónoma, puede emitir a fin de corregir carencias que haya detectado (en las experiencias reseñadas, información que tenía que ser dada a publicidad) sin que medie ley previa. Esas reglamentaciones aparecen como proactivas y previsoras. El dictado de reglamentos internos, que trasuntan el ejercicio de competencia reglamentaria autónoma no necesitada de una ley previa, estará sujeto al claro límite de las materias reservadas al Legislador (por ejemplo, mediante un reglamento interno del artículo 113 no se podría crear una cámara federal de apelaciones). Por último, cuando se halle en juego el ejercicio de competencia reglamentaria autónoma bajo ese artículo de la Constitución, y no obstante ello medie ley previa, se impone, en la etapa de proyecto y sanción del reglamento interno respectivo bajo el artículo 113, detectar posibles avances del Legislador o incluso alguna imprevisión o desconocimiento por parte de este. Resultará clave, en este aspecto, una buena liaison comunicacional entre las ramas judicial y legislativa de gobierno.

\subsection{Rango infraconstitucional}

Diversas leyes habilitaron a la Corte Suprema para ejercer competencia regla-

34 Acordada s.n., Reglamento para la Justicia Nacional, del 17/12/1952, BO 22/04/1953, publicada en Fallos: 224:575, artículo 33: "Las cámaras y los juzgados llevarán un registro de sus funcionarios, empleados y meritorios con los datos que se requieran en las planillas que a ese efecto distribuirá la Corte Suprema [...]".

Acordada 42/2017, del 27/12/2017. 
mentaria. Ya en 1862, la Ley 27, ${ }^{36}$ artículo 11 estableció que: "La Corte nombrará y podrá remover sus empleados subalternos. Además de su reglamento interno, dictará otro uniforme para todos los Juzgados de Sección [...]”; este último fue dictado el 12 de octubre de $1863 .{ }^{37} \mathrm{~A}$ su turno, la Ley $48,{ }^{38}$ de 1863 , en su artículo 18 prescribió: "La Corte Suprema podrá establecer los reglamentos necesarios para la ordenada tramitación de los pleitos, con tal que no sean repugnantes a las prescripciones de la Ley de Procedimientos”. De este lenguaje puede inferirse, literalmente, que el límite estaba dado por esa ley procedimental (por ejemplo, no agraviar el debido proceso o la defensa en juicio, tal vez mediante una sentencia no motivada). ${ }^{39}$ Con visión más general, y dentro de la lógica de la supremacía constitucional, podría también haberse inferido que el límite estaba dado por la Norma Fundamental misma, ya que no se podrían haber dictado reglamentos repugnantes a esta.

Asimismo, la Ley $4055,{ }^{40}$ de 1902, fijó un deber en materia reglamentaria en su artículo 10: "La Suprema Corte [deberá] dictar los reglamentos convenientes para procurar la mejor administración de justicia”. Nótese, en este texto, el límite dado por la "mejor" administración de justicia.

Por su parte, la Ley $13998,{ }^{41}$ de 1950, sobre integración de la justicia federal y la local de la Capital Federal, en su artículo 21 estableció: "La Corte Suprema de Justicia [...] [d]ictará su reglamento interno y económico y ejercerá superintendencia sobre todos los tribunales de la Nación, en la forma que se establezca en sus reglamentos". En este texto se suma el capítulo "económico" y también se adicionan los reglamentos de superintendencia sobre todos los tribunales de la nación.

Posteriormente, el Decreto-ley 1285/1958 ${ }^{42}$ incluyó en su artículo referencias a la pluralidad de reglamentos de la Corte Suprema. ${ }^{43}$ Empero, su artículo

36 Ley 27, del 13/10/1862, R.N, tomo IV 1857-1862, p. 496.

37 Reglamento para los juzgados seccionales, Fallos: 1:11, del 12/10/1863.

38 Ley 48, del 14/09/1863, R.N., tomo 1863-1869, p. 49.

39 Ampliar en Garay (2015, p. 17, nota al pie 34) in fine, donde se refiere a los artículos 13 y 14 de la Ley 50 , del 25/08/1863.

40 Ley 4055, del 8/01/1902, R.N., tomo 1902-I, p. 100.

41 Ley 13998, BO 11/10/1950.

42 Decreto-ley 1285/1958, BO 7/02/1958, ratificado por la Ley 14467, BO 29/09/1958.

43 Decreto-ley 1285/1958, BO 7/02/1958, ratificado por la Ley 14467, BO 29/09/1958, artículo 12 (prescindencia del título de abogado); artículo 13 (forma de nombramiento y remoción de funcionarios y empleados que dependan de la Justicia de la Nación y otras cuestiones vinculadas a ellos); artículo 15 (derechos, deberes, responsabilidades e incompatibilidades de magistrados, funcionarios, 
21 -que reiteraba que la Corte Suprema "dictará su reglamento interno y económico y el reglamento para la Justicia nacional, estableciendo las facultades de superintendencia de la Corte Suprema y tribunales inferiores"- fue modificado en 2013 por la Ley 26853,44 artículo 13, eliminándose ese texto entrecomillado y substituyéndolo por otro que establece la cantidad de jueces de la Corte Suprema, y, en virtud de su artículo 4, la Ley 27500 derogó casi toda "la ley 26.853 , excepto su artículo 13", que, como vimos, establece la cantidad de jueces de la Corte Suprema.

Finalmente, la Ley 25488, ${ }^{45}$ de 2001, de modificación del Código Procesal Civil y Comercial de la Nación (CPCCN), en su artículo 4 estableció: "[...] La Corte Suprema de Justicia de la Nación queda facultada para dictar las medidas reglamentarias y todas las que considere adecuadas para el mejor cumplimiento de las normas y fines de esta reforma". ${ }^{46}$

\subsection{1. ¿Qué evidencian estas leyes?}

Todas las leyes recién enumeradas, a primera vista, reconocen o atribuyen poder reglamentario en la Corte Suprema.

Se tratará, por cierto, de aquella porción de poder reglamentario que asiste a la Corte Suprema "por fuera" del artículo 113 de la CN. Ello, pues, como vimos en el apartado 2.1.2., el artículo 113 coloca directamente en cabeza de

empleados y auxiliares de la Justicia de la Nación); artículo 16 (sanciones a magistrados, funcionarios, empleados y auxiliares de la Justicia de la Nación); artículo 23 (facultad de la Corte de dividirse en salas); artículo 25 (deber de las cámaras nacionales de apelaciones de dividirse en salas); artículo 48 (reglamentar la organización y funcionamiento de la oficina de mandamientos y notificaciones, sobre la cual la Corte Suprema ejerce superintendencia); artículo 52 (reglamentos de auxiliares de la justicia nacional); artículo 53 (reglamentos de la Corte Suprema para designación y remoción de empleados); artículo 58 (reglamentos con recaudos sobre presentes en actos de autopsia); artículo 61 (reglamentos de la Corte Suprema sobre peritos ingenieros o traductores); artículo 62 (reglamentos de distribución de tareas).

44 Ley 26853 de creación de cámaras federales de casación, BO 17/05/2013 (vigencia: a partir de su publicación; una vez constituidas las Cámaras y Salas creadas por la Ley 26853, será de aplicación a todos los juicios, aún a los que se encuentren en trámite).

45 Ley 25488, BO 22/11/2001, modificatoria del CPCCN.

46 Además, en el articulado del CPCCN se prevén diversos reglamentos de la Corte Suprema: así, el artículo 455 sobre reglamento de determinación de funcionarios exceptuados de la obligación de comparecer a prestar declaración; el artículo 570 sobre reglamento, emanado de la Corte Suprema o las cámaras, sobre subastas progresivas, entre otros supuestos. Sin embargo, la Corte Suprema, en Sprayette (no publicado en la Colección de Fallos, del 1/07/2014) no aludió al ejercicio de una competencia "delegada" por la Ley 25488, sino a la potestad "reconocida" por el artículo 18 de la Ley 48, facultad “inalterada” por otras leyes, incluyendo la Ley 25488 (considerando 2). 
la Corte Suprema -por "delegación" del Constituyente, si se quiere, o, mejor dicho, por "creación" de este- una competencia reglamentaria de fuente textual constitucional enderezada primigeniamente al plano intrapoder, internamente interorgánico, sin perjuicio de eventuales efectos o beneficios hacia terceros. Esa competencia originada en el artículo 113 habilita el dictado de lo que denominamos "reglamentos autónomos" emanados de la Corte Suprema, no dependientes de una ley previa, reglamentos autónomos sujetos a los límites y advertencias ya sugeridos.

En cambio, en el campo de los artículos transcriptos precedentemente, estamos ante materias no ya internas, administrativas en sentido genérico (por oposición a jurisdiccional), sino ante materias propias de la jurisdicción que ya han comenzado a tener "principio de regulación" o "principio de reglamentación" por el Congreso bajo el artículo 75, inciso 20 de la CN o bajo los artículos 116 y 117 de la CN.

\subsubsection{Abordaje epistemológico}

La muestra legislativa reseñada, entonces -con exclusión de toda referencia a un "reglamento interno" por corresponder este a la provincia del artículo 113 de la $\mathrm{CN}_{-}$, es pasible de ser visualizada, al menos, desde dos plataformas epistemológicas alternativas.

Por un lado, esas leyes pueden concebirse como "leyes delegantes" del Congreso (delegante) a favor de la Corte Suprema (delegataria o recipiente de la delegación legislativa), que redundarán en "reglamentos delegados" emanados de esta.

Por otro lado, también puede apreciárselas como "leyes pasibles de reglamentación de ejecución de las leyes”, v.gr., leyes que en sí mismas fijan lineamientos generales que la Corte Suprema reglamentará mediante lo que conocemos como "reglamentos de ejecución de las leyes".

Así, aparecerá replicado en esta propuesta interpretativa y respecto a la Corte Suprema lo que se advierte sobre la competencia reglamentaria del Poder Ejecutivo, bajo el artículo 76 de la CN y bajo el artículo 99, inciso 2 de la CN, los cuales, respectivamente, habilitan al titular del Poder Ejecutivo a dictar reglamentos delegados y reglamentos de ejecución de las leyes. ${ }^{47}$

Veamos, ahora, lo relativo a cada una de esas dos plataformas de análisis.

47 El paralelo con los restantes poderes puede construirse a partir de la máxima según la cual la Corte Suprema "representa en la esfera de sus atribuciones, la soberanía nacional, y es 


\subsubsection{Delegación legislativa en la Corte Suprema}

Es menester formular una casi innecesaria distinción entre lo que en el apartado 2.1. me permití denominar "delegación" (o, tal vez, "creación") del Constituyente a favor de la Corte Suprema bajo el artículo 113 de la CN, que habilita a la Corte Suprema a dictar reglamentos autónomos, por un lado, y, por el otro, el supuesto de competencias que el Legislador delega en el máximo Tribunal luego de haber legislado la materia bajo el artículo 75, inciso 20 de la CN, o bajo los artículos 116 y 117 de la $\mathrm{CN},{ }^{48}$ supuestos en los que el Legislador fija el estándar y la Corte Suprema provee los detalles.

A modo de ejemplo, comparemos el dictado por la Corte Suprema de, por un lado, su régimen de contrataciones, medida de alcance general de tenor primordialmente interno sin perjuicio de sus efectos y tal vez beneficios hacia terceros, y, por otro lado, la reglamentación de las formalidades del recurso extraordinario de la Ley 48. En el primer caso, la competencia surge del artículo 113 de la CN y se manifestará en reglamentos autónomos; en el segundo, se tratará de una competencia normativa emanada del órgano judicial especializado, enderezada a proveer los detalles de la ley formal. En un caso se tratará de una atribución dispuesta por el Constituyente que no requiere ley previa (Bielsa, 1959, p. 753); en el segundo caso se dictarán reglamentos sobre tramitación de ciertos pleitos, cuyas disposiciones "vinculan a los tribunales con las partes o litigantes respecto de ciertos actos, por lo que no pueden llamarse internos [...] sino delegados" (Bielsa, 1959, p. 753) ${ }^{49}$ aspecto en el que coincide Bianchi (1990, p. 231).

La distinción formulada halla quicio en Fabris, ${ }^{50}$ en el cual se consideró que las acordadas en cuestión habían sido dictadas en virtud de una "competencia delegada" por una ley del Congreso. En el mismo lugar se diferenció entre este ejercicio de esa competencia delegada, por un lado, y la competencia privativa que habilita el artículo 113 de la CN para dictar el reglamento interno, por el otro. ${ }^{51}$

tan independiente en su ejercicio como el Congreso en su potestad de legislar, y como el Poder Ejecutivo en el desempeño de sus funciones”, cfr. Fisco Nacional c/Ocampo, Manuel, Fallos: 12:134, del 8/08/1872, esp. p. 155.

48 Ver, por ejemplo, Rabinovich, Héctor c/Videla, Horacio Germán y otros, Fallos: 315:2113, del 17/09/1992; Basso, Jorge c/ocupantes Hipólito Yrigoyen 4117/21, Fallos: 317:547, del 31/05/1994.

49 Énfasis en el original.

50 Fabris, Marcelo H. c/Estado Nacional (Poder Judicial de la Nación), Fallos: 311:1517, del 22/08/1988. En igual sentido, Herrera, Lucio Eduardo c/Estado Nacional s/nulidad de resolución y cobro de haber, Fallos: 313:427, del 6/04/1990.

51 Fabris, Marcelo H. c/Estado Nacional (Poder Judicial de la Nación), Fallos: 311:1517, del 22/08/1988, 
Esta posibilidad de delegación legislativa, con el Congreso como delegante a favor de la Corte Suprema como delegataria, mediante una ley habilitante cuya materia sea proveniente del artículo 75, inciso 20 de la CN, o de los artículos 116 y 117 de la CN, halla hoy fundamentos no solo en la doctrina (Bianchi, 1990, pp. 231-232; Bielsa, 1959, p. 752), sino también en:

1. una lectura originalista del artículo 76 de la $\mathrm{CN}$, emanado de un Constituyente de 1994 centrado en evitar la experiencia generada por el fallo Cocchia $^{52}$ de 1993, pero no tan preocupado respecto a otras ramas de gobierno en tanto delegatarias;

2. una lectura apegada al texto del artículo 76 de la $\mathrm{CN}$, tal que la prohibición recaiga únicamente sobre el Poder Ejecutivo y le esté permitido al Congreso delegar en un órgano que no sea el Poder Ejecutivo; ${ }^{53}$

3. la invocación de los poderes implícitos del Congreso, que le permiten a este dictar leyes delegantes con la Corte Suprema como delegataria para poner en ejercicio los poderes del artículo 75 de la $\mathrm{CN} ; ;^{54}$

4. la experiencia histórica nos enseña que la Ley $48,{ }^{55}$ de 1863 , artículo 18 (ya transcripto y vigente) ${ }^{56}$ delegó, en forma expresa y limitada, en la Corte Suprema el establecimiento de aquellos reglamentos necesarios para la ordenada tramitación de los pleitos, y el ejercicio de esa delegación se puso de manifiesto en diversas acordadas en las que se ejerció poder delegado por la norma citada con expresa invocación de esta; ${ }^{57}$

considerando 4 .

52 Cocchia, Jorge Daniel c/Estado Nacional y otro s/acción de amparo, Fallos: 316:2624, del 2/12/1993. En el caso, se convalidó la modificación de un convenio colectivo de trabajo mediante un reglamento delegado. Ampliar en: Santiago (2014, pp. 1398-1400).

53 Este argumento es recordado, dentro de una "tesis permisiva” en Sagüés (2019, pp. 395-400), esp. p. 396, en la que lo califica como "argumento clave".

54 Idem nota al pie 50, supra.

55 Ley 48, del 14/09/1863, R.N., tomo 1863-1869, p. 49.

56 No podría decirse que lo previsto en el artículo 18 de la Ley 48 quedó tácitamente abrogado por el Decreto 1285/1958; este, como ya vimos, menciona diversos reglamentos dictados o a dictarse; en cambio, aquel fija una competencia con carácter genérico y asertivo.

57 Ver, citando el artículo 18 de la Ley 48 en forma expresa: "Acuerdo disponiendo la distribución de causas, turno y forma de reemplazo de los jueces federales de las secciones de Buenos Aires y Santa Fe, Fallos: 82:12, del 4/02/1902; Acuerdo disponiendo la distribución de causas, turno, personal de los juzgados federales de Rosario, Fallos: 99:13, del 19/02/1907; Acuerdo disponiendo la distribución de causas y determinando el turno de los procuradores fiscales en lo federal de la sección de la Capital, Fallos: 99:16, del 13/04/1907; Acuerdo disponiendo la distribución de causas y determinando el turno de los defensores de pobres, incapaces y ausentes ante la Justicia federal de la Capital, Fallos: 99:17, del 28/05/1907; Turnos de los defensores oficiales de la Capital, Fallos: 201:8, del 11/08/1944; Turno de los procuradores fiscales, Fallos: 207:12, del 31/12/1946, entre otros. 
5. en el plano fáctico, con posterioridad a 1994, se sancionaron leyes que delegan competencias normativas en el Alto Tribunal; así, por ejemplo, la Ley 25488, modificatoria del CPCCN, ${ }^{58}$ o la Ley $26855,{ }^{59}$ y no cabe imaginar la inconsecuencia del Legislador al sancionar esas leyes conociendo la prohibición establecida en el artículo 76 de la CN y los bordes exactos de sus alcances;

6. fundamentos de especialización tornan a la Corte Suprema en idónea a los fines de reglamentar la ley, delegación del legislador mediante, y a su know how se le suma la posible rapidez en el obrar, pues es un cuerpo colegiado reducido; ${ }^{60}$

7. la propia Corte Suprema ha afirmado que la reforma constitucional de 1994

Más modernamente cabe citar la Acordada 28/2004, Amigos del Tribunal, BO 20/07/2004, del 14/07/2004, considerando 3o con cita del artículo 18 de la Ley 48; y la Acordada 12/2016, Reglamento de actuación en procesos colectivos, BO 8/04/2016, del 5/04/2016, considerando $9^{\circ}$ con cita del artículo 18 de la Ley 48 y atento a la ausencia de una ley reguladora de esa clase de procesos según se considera en su considerando $10^{\circ}$.

Empero, nótese que la mayoría que suscribe la Acordada 4/2007, BO 21/03/2007, del 21/03/2007, sobre recurso extraordinario y recurso de queja por denegación, considerando $2^{\circ}$ cita "la ley del 14 de septiembre de 1863”, es decir, la Ley 48, pero sin individualización de su artículo 18. Ello, a diferencia del voto del juez Fayt en dicha acordada, que considera que "la sistematización de los recaudos de que se trata sólo pone en ejercicio las atribuciones estrictamente reglamentarias, con que cuenta esta Corte en los precisos y concordes términos contemplados por los arts. 18 de la ley 48 [...]”.

58 Ley 25488, citada en nota al pie 38, supra, cuyo artículo 4 establece que "La Corte Suprema de Justicia de la Nación queda facultada para dictar las medidas reglamentarias y todas las que considere adecuadas para el mejor cumplimiento de las normas y fines de esta reforma". Sin embargo, en la Acordada 20/2012, del 30/10/2012, se considera que bajo el artículo 4 de la Ley 25488 "corresponde a la Corte Suprema la facultad de dictar las medias reglamentarias [...]", sin aludirse a delegación legislativa alguna.

59 Ley 26855, BO 27/05/2013, modificatoria de la Ley 23853, BO 24/10/1990, que establece que la Corte Suprema de Justicia de la Nación preparará el presupuesto de gastos y recursos del Poder Judicial de la Nación. El artículo 8 de la Ley 23853 hoy establece: "A los fines establecidos en la presente ley y bajo el estricto respeto a los principios de transparencia en la gestión y eficiencia en el uso de los recursos, la Corte Suprema de Justicia de la Nación tendrá amplias facultades para establecer aranceles y fijar sus montos y actualizaciones [...]".

Se convalidó dicha delegación en Asociación por los Derechos Civiles c/Estado Nacional Ley $26124 \mathrm{~s} /$ amparo, Fallos: 333:1251, del 3/08/2010, esp. considerando 5: "[...] el artículo 8 de la ley 23.853, confirió a la Corte la facultad de establecer aranceles y fijar sus montos y actualizaciones, [...] y dentro de esa delegación de atribuciones se encuentra la posibilidad de adecuar el monto proporcional o fijo de la queja establecida en el artículo 286 del Código Procesal Civil y Comercial de la Nación [...]". También se invoca la "delegación de atribuciones" a favor de la Corte Suprema en Oviedo, Carlos Alberto c/Marcone, Élida y otro, Fallos: 331:419, del 11/03/2008; Thierbach, Carlos Alberto c/ Macellaro, Jorge Carlos y otro s/consignación, Fallos: 330:3771, del 28/08/2007; Fontenova, Humberto y otra c/Sala, Arturo Julio y otra, Fallos: 330:2900, del 3/07/2007, entre otros.

En cierto modo, es como un regreso a Vila, Juan Diego c/Corte Suprema de Justicia de la Nación, Fallos: 310:576, del 9/03/1987, considerando $11^{\circ}$, en el que se aludió a "la ley 23199 que delegó en la Corte la reglamentación [...]”, agregándose que esta, mediante las Acordadas 43 y 50, no excedía notoriamente los alcances de la ley.

60 Ver Sagüés (2019, p. 399), quien advierte que las dificultades en la labor reglamentaria del Alto Tribunal se sobrellevan si esta es "limitada a cuestiones tribunalicias, particularmente procesales". 
no ha modificado la delegación del Legislador por medio del artículo 8 de la Ley 23853 de Autarquía Judicial; $; 1$

8. un argumento hábil, asimismo, para despejar dudas sobre la viabilidad de esa delegación legislativa a favor de la Corte Suprema -en especial atento al "plazo" requerido en el artículo 76 de la $\mathrm{CN}$ - hace a las características propias de las normas reguladoras de cuestiones jurisdiccionales: los cambios en ellas son infrecuentes ${ }^{62}$ y ello demuestra, además de confianza del Legislador hacia la Corte Suprema y su potestad reglamentaria para reglar detalles de esas leyes (como para hacerla beneficiaria de delegación o atribución de competencias normativas), la procedencia de una distinta visión del "plazo de la delegación", inaplicable como recaudo a la delegación de atribuciones a la Corte Suprema para reglamentar aspectos propios de su labor jurisdiccional. ${ }^{63}$

Por cierto, la delegación del Poder Legislativo a favor de la Corte Suprema excluirá las materias involucradas en la delegación del Constituyente a favor del Consejo de la Magistratura de la Nación en el artículo 114, inciso 6 de la $\mathrm{CN}$. Ello se debe, primero, a que hay áreas que la Constitución enuncia como propias de dicho Consejo (Badeni, 2010, p. 837); segundo, a que el Congreso no podría "delegar en la Corte Suprema algo que constitucionalmente no es suyo sino del Consejo" (Sagüés, 2019, p. 396), sin perjuicio de las potestades de revisión judicial última de la Corte Suprema, ${ }^{64}$

Por último, la experiencia estadounidense sobre competencia reglamentaria que la Corte Suprema recibe por delegación del Legislador enseña sobre una

61 Ampliar en Castro Videla y Maqueda Fourcade (2018, pp. 147-150) con cita de Asociación por los Derechos Civiles c/Estado Nacional - Ley 26122 s/amparo, Fallos: 333:1254, del 3/08/2010, considerando $5^{\circ}$ y sus citas de Fontenova, Humberto y otra c/Sala, Arturo Julio y otra, Fallos: 330:2900, del 3/07/2007. Acerca de la Ley 23853 de Autarquía Judicial y las facultades por ella otorgadas a la Corte Suprema, ver Santiago (2014, pp. 1324-1325).

62 Consideremos entre 1991 y 2012: La Ley 23774, BO 16/04/1990, con el artículo 280 para desestimar apelaciones extraordinarias carentes de trascendencia; la Ley 25587, BO 26/04/2002, o ley antigoteo, que derogó el recurso del 195bis del CPCCN para recurrir medidas cautelares; la Ley 26025, BO 22/04/2005, de solidaridad previsional, que derogó el recurso ordinario previsional; la Ley 26790, BO 4/12/2012, que estableció el recurso extraordinario por salto de instancia (per saltum).

63 No percibo que ello implique construir una provincia de delegación legislativa por fuera del artículo 76 de la $\mathrm{CN}$, sino leer dicho artículo de cara a un valor o finalidad -llevar adelante la labor jurisdiccional- ajeno a las materias de Administración o a la emergencia.

64 Acerca de esta calidad de la Corte Suprema como intérprete final, ver Sacristán (2017, pp. 143-151). 
primera manifestación en la Judiciary Act de $1789 .{ }^{65}$ Esa muestra fue potenciada, muchos años después, en la Rules Enabling Act ${ }^{66}$ de 1934 (preanunciada por la convalidación jurisprudencial de la delegación en Wayman v. Southard, de 1825$)^{67}$. Podría decirse que este esquema delegativo que asigna poder discrecional para emitir reglas al órgano judicial responde a un enfoque que hoy no diferiría tanto de la competencia que, por delegación del Legislador, la Corte Suprema argentina recibe bajo la Ley 25488, ${ }^{68}$ de 2001, artículo 4 ("dictar las medidas reglamentarias y todas las que considere adecuadas para el mejor cumplimiento de las normas y fines de esta reforma"). Pero más allá del "esquema", el "alcance" de la delegación en la Corte Suprema argentina, bajo el precitado artículo 4 en tanto leído literalmente, podría visualizarse como menos amplio por verse acotado a ese mejor cumplimiento "de las normas y fines" de la reforma procesal. Empero, acordadas dictadas con posterioridad a 2001 podrían llevar a una conclusión diversa: un criterio amplio, no acotado a esa reforma. ${ }^{69}$

Más allá del alcance menos o más amplio que pueda merecer la delegación bajo el artículo 4, lo cierto es que la delegación legislativa a favor de la Corte Suprema -huelga reiterarlo- es ajena al artículo 113 de la CN (norma que, además, no tiene paralelo en la Constitución estadounidense) y mora en la provincia de los artículos 75, inciso 20 y 116 y 117 de la CN. ${ }^{70}$

65 Statute I. Sept 24, 1789, Chap. XX. An Act to establish the Judicial Courts of the United States, First Congress, Sess. I, Ch. 20. 1789 Disponible en: https://memory.loc.gov/cgi-bin/ ampage? collid $=11$ sl\& fileName $=001 / 11 s 1001$.db\& recNum $=214$.

Su Sección 32 establecía que cualquiera de los courts estadounidenses podría, discrecionalmente, prescribir reglas procesales ("And the said courts respectively shall and may, by virtue of this act, from time to time, amend all and every such imperfections, defects and wants of form [...] and may, at any time permit either of the parties to amend any defect in the process or pleadings, upon such conditions as said courts respectively shall, in their discretion, and by their rules prescribe"). Es clara la influencia de la consagración de esta potestad reglamentaria o de emisión discrecional de reglas en el texto del artículo 18 de la Ley 48.

66 Rules Enabling Act, 28 U.S.C., § 2071.

67 Wayman v. Southard, 23 U.S. (10 Wheat.) 1 (1825), sobre delegación del Congreso federal en las legislaturas locales, esp. pp. 22-23: "No se sostendrá que el Congreso puede delegar, en los tribunales o en cualquier otra corte, facultades que son estricta y exclusivamente legislativas. Pero el Congreso ciertamente puede delegar, a otros, poderes que la legislatura podría legítimamente ejercer por sí" ("It will not be contended that Congress can delegate to the courts or to any other tribunals powers which are strictly and exclusively legislative. But Congress may certainly delegate to others powers which the legislature may rightfully exercise itself"). Ampliar en Bianchi (1990, p. 232); Whittington y Iuliano (2017, pp. 394-395).

68 Ley 25488, BO 22/11/2001, modificatoria del CPCCN.

69 Ver, por ejemplo, Acordada 32/2014 de Reglamento de Actuación en Procesos Colectivos, considerando $9^{\circ}$ in fine, con expresa invocación del artículo 4 de la Ley 25488.

70 Confrontar disidencia de los jueces Belluscio, Fayt y Vázquez en Acordada 28/2004, Amigos del Tri- 
Es claro que el campo de acción de las dos leyes estadounidenses mencionadas alcanza a tribunales federales no comprendidos en los límites del presente trabajo. Nótese, en especial, que la Rules Enabling Act, en su § 2071, establece: "La Corte Suprema y todos los tribunales creados por ley del Congreso pueden, de tanto en tanto, prescribir reglas para la conducción de su quehacer. Tales reglas serán coherentes con las leyes del Congreso y las reglas de práctica y procedimiento prescriptas bajo $§ 2072$ de este título". ${ }^{71}$

Ciertamente, y como acotación adicional relativa a nuestro ordenamiento, el ejercicio de competencia delegada traerá aparejadas facultades expresas y, además, implícitas. ${ }^{72}$

\subsubsection{Ejecución de leyes del Congreso por la Corte Suprema}

Desde una perspectiva alternativa, también puede advertirse en la actividad reglamentaria de la Corte Suprema una labor de puesta en ejecución de las leyes sin que medie una expresa delegación y en un contexto en el que se impone reglamentar o proveer detalles a los fines de posibilitar la aplicación de la ley formal mediante "reglamentos de ejecución" o "reglamentos ejecutivos", como los que puede dictar el Poder Ejecutivo bajo el artículo 99, inciso 2 de la CN. Nuevamente, se tratará de leyes cuya materia sea la del artículo 75, inciso 20 de la $\mathrm{CN}$ o la de los artículos 116 y 117 de la CN y que requieran reglamentación.

Ejemplos antiguos pueden divisarse en una acordada de 1919, "reglamentando la Ley 10996", ${ }^{73}$ o en una resolución dictada en torno a la aplicación de la Ley $14237,{ }^{74}$ en la cual se consideró "conducente" declarar "por vía reglamentaria" cuál iba a ser el campo de aplicación de esa ley. Otro ejemplo surge

bunal, BO 20/07/2004, del 14/07/2004, Fallos: 327:2997, esp. considerando 2o, en el que rechazan la posibilidad de que se dicte dicha Acordada bajo el artículo 113 de la CN, cuando la mayoría, en el considerando $3^{\circ}$, invoca el artículo 18 de la Ley 48. En otras palabras, lo que la disidencia concibe como un reglamento autónomo es, con todo acierto para la mayoría, un reglamento delegado.

71 "The Supreme Court and all courts established by Act of Congress may from time to time prescribe rules for the conduct of their business. Such rules shall be consistent with Acts of Congress and rules of practice and procedure prescribed under section 2072 of this title".

72 Ver, a modo de ejemplo, Acordada sobre constitución de los tribunales de enjuiciamiento de los magistrados de la Justicia nacional, Fallos: 215:365, esp. p. 365.

73 Acordada dictada por la Corte Suprema de la Nación reglamentando la ley número 10996 sobre el ejercicio de la procuración, Fallos: 131:5, del 29/11/1919.

74 Aplicación de las disposiciones de la Ley 14237, Fallos: 228:45, del 8/03/1954. La Ley 14237, BO 19/10/1953, derogada por la Ley 17454, BO 7/11/1967, modificó el Código de Procedimiento en lo Civil y Comercial en la Capital Federal. 
de Siragusa, en el que la propia Corte Suprema calificó a su acordada como "reglamentaria de la ley". ${ }^{75}$ También se detecta espacio para la ejecución de leyes en la Ley $26685,{ }^{76}$ de 2011, por la cual la Corte Suprema y el Consejo de la Magistratura de la Nación, conjuntamente, "reglamentarán” la utilización del expediente electrónico.

\subsubsection{Efectos}

Tanto el ejercicio de la competencia reglamentaria por mediar delegación legislativa como la resultante del ejercicio de facultades para poner en ejecución la ley poseen la virtualidad de poder redundar, en la pirámide de la Justicia federal, en delegación intrajudicial, interorgánica, por parte de la Corte Suprema a favor de las Cámaras federales. ${ }^{77}$ Similar razonamiento es aplicable al supuesto de delegación a favor del Consejo de la Magistratura, ${ }^{78}$ hipótesis que se confirma con la Corte Suprema como revisora última de las decisiones de aquel.

\subsubsection{Las materias de la delegación o de la ejecución de las leyes}

Se adopte una u otra visión respecto a la ley de Congreso en tanto habilitante de la competencia reglamentaria de la Corte Suprema por delegación legislativa o por ejecución de las leyes, es claro que la principal limitación surgirá de la materia de la ley.

Ya dijimos que nos hallamos, en este campo, no ya ante competencia autónoma dispuesta por el artículo 113 de la $\mathrm{CN}$, sino ante leyes dictadas al amparo de los artículos 116 y 117 de la CN o del artículo 75, inciso 20 de la CN, que dejan

75 Siragusa Virzi, Eugenio, Fallos: 285:391, del 3/05/1973, con remisión al dictamen de la Procuración General, esp. 392.

76 Ley 26685, BO 7/07/2011, que establece: "Artículo 1. Autorízase la utilización de expedientes electrónicos, documentos electrónicos, firmas electrónicas, firmas digitales, comunicaciones electrónicas y domicilios electrónicos constituidos, en todos los procesos judiciales y administrativos que se tramitan ante el Poder Judicial de la Nación, con idéntica eficacia jurídica y valor probatorio que sus equivalentes convencionales. Artículo 2०: La Corte Suprema de Justicia de la Nación y el Consejo de la Magistratura de la Nación, de manera conjunta, reglamentarán su utilización y dispondrán su gradual implementación”.

77 Corte Suprema de Justicia de la Nación, Guardia, Carlos Eduardo y otra, Fallos: 307:1466, del 22/08/1985, considerando $11^{\circ}$, con cita de la Acordada 65/1984, del 23/10/1984. Un ejemplo puede verse en: Acordada 20/1981, Fallos: 302:25, del 25/06/1981.

78 Ver Acordada 11/2004, del 25/03/2004, título y artículo 1'; Acordada 26/2007, del 25/10/2007, artículo II. 
espacio para el ejercicio de competencia delegada o para la ejecución de las leyes por parte de la Corte Suprema. Nos hallaremos, por ende, ante lo que genéricamente podemos denominar "leyes de organización del Poder Judicial". Esas leyes comprenderán, desde un punto de vista general, dos grupos: (i) leyes que establezcan estructuras y sus competencias; y (ii) leyes que fijen los procedimientos.

Como ejemplo de ley de establecimiento de estructura y asignación de competencia consideremos el supuesto de la "Sala Electoral", creada por la Ley 19108, ${ }^{79}$ de 1971, dentro la Cámara Nacional de Apelaciones en lo Federal y Contencioso Administrativo de la Capital Federal y que posteriormente, por la Ley 19277, fue transformada en la Cámara Nacional Electoral, con su estructura actual de tres jueces conformando una única sala. Este tipo de ley, por su materia, halla fuente en el artículo 75, inciso 20.

Como ejemplo de leyes que establecen procedimientos, consideremos la Ley $48,{ }^{80}$ en especial sus artículos 14 a 16, así como el artículo 24, inciso 2 del Decreto 1285/1958, ${ }^{81}$ que establece que la Corte Suprema conocerá "por recurso extraordinario en los casos de los artículos 14 de la ley 48 [...]”, o los artículos 256 a 258 del CPCCN sobre "apelación extraordinaria ante la Corte Suprema”, o el artículo 286 del CPCCN, que establece el depósito por interposición de recurso de queja por denegación de recurso extraordinario. Este tipo de leyes, por su materia, enraíza en los artículos 116 y 117 de la CN.

Tanto las leyes del primer grupo como las del segundo son reglamentables por la Corte Suprema. Consideremos la Acordada 21/2007, ${ }^{82}$ del 30/08/2007, que autorizó a la Cámara Nacional Electoral a disponer de los ingresos que obtenga en concepto de aranceles; o la Acordada 4/2007, ${ }^{83}$ reguladora de las formalidades de los recursos extraordinarios y de queja; o la Acordada 40/2019, 84 que establece en 100 mil pesos el respectivo depósito.

79 Ley 19108, BO 12/07/1971, de Cámara Federal y Contencioso Administrativo.

80 Ley 48, del 14/09/1863, R.N., tomo 1863-1869, p. 49.

81 Decreto-ley 1285/1958, BO 7/02/1958, ratificado por la Ley 14467, BO 29/09/1958.

82 Acordada 21/2007, del 30/08/2007.

83 Acordada 4/2007, BO 21/03/2007, del 21/03/2007.

84 Acordada 40/2019, BO 30/12/2019. Acerca de la fijación de tal monto por delegación legislativa en la Corte Suprema y la convalidación de aquella, ver, con provecho, Castro Videla y Maqueda Fourcade (2018, pp. 147-150). 


\subsubsection{Límites que acotan la potestad reglamentaria, delegada o de ejecución de las leyes, de la Corte Suprema}

Pueden esbozarse aquí diversos límites que pesan sobre el ejercicio de la potestad reglamentaria de la Corte Suprema cuando ejerce competencia que le ha sido delegada por el Congreso o cuando dicta reglamentos de ejecución de la ley.

Primero, no podrían afectar el derecho de defensa ni el debido proceso, de raigambre constitucional, sea en su faz adjetiva como sustantiva, como sería el supuesto en el que se afecte la autonomía de la voluntad, ${ }^{85} \mathrm{y}$ en general no podría desoír la manda de razonabilidad del artículo 28 de la CN.

Asimismo, limitan la labor reglamentaria de la Corte Suprema las materias de reserva del Legislador. ${ }^{86}$

Además, el límite dado por la "mejor" administración de justicia, que parece privilegiar la eficacia de la labor jurisdiccional, no puede hacer caso omiso de requerimientos propios de una república, cual el acceso a las razones que motivan las decisiones del órgano estatal. ${ }^{87} \mathrm{Y}$ las consideraciones de eficacia no podrían hacer soslayar consideraciones de eficiencia. ${ }^{88}$

Por otro lado, la reglamentación judicial, enderezada a la ordenada tramitación de los pleitos, no puede ser repugnante a las prescripciones de la ley. ${ }^{89}$ Es más, la calidad de regulador -o de emisor de reglas- que poseen los tribunales

85 Bajo la Acordada 12/2016, Reglamento de actuación en procesos colectivos, BO 8/04/2016, del 5/04/2016, el juez determina "los medios más idóneos para hacer saber a los demás integrantes del colectivo la existencia del proceso" (artículo VIII.2.), lo cual no es indicativo ni de opt-in ni de opt-out. Sin embargo, la experiencia nos muestra cómo el fallo CEPIS tuvo efectos expansivos alcanzando al colectivo de usuarios residenciales (excluyendo los usuarios pasibles de tarifa social) del servicio de gas, usuarios residenciales que no podían optar por quedar fuera (opt-out) de los efectos del fallo por hallarse la licenciataria bajo el deber de acatarlo. En otras palabras, un régimen de opt-out es, de hecho, autoritario y avasalla la autonomía de la voluntad, pues no se elige, sino que se padece la inclusión en el colectivo judicialmente definido; ampliar en Sacristán (2016, pp. 199-213) y sus citas en pp. 215-216 de Phillips Petroleum Co. v. Shutts, 472 U.S. 797 (1985). Confrontar, mencionando la posibilidad de certificación de una clase mandatoria sin posibilidades de opt-out, Oyhanarte (2015, p. 498).

86 Por ejemplo, se ha afirmado que la extensión de los plazos procesales solo puede establecerse mediante ley y no por acordada, cfr. Silva, Aníbal, Fallos: 275:49, del 8/10/1969. Una definición brindada en la ley no puede ser modificada por medio de una acordada; cfr. dictamen de la Procuración General, al que remitió la Corte Suprema, en Arakaki, Marcela Noemi y otros c/E.N. - C.S.J.N. - Ac. 57/1992 s/empleo público, Fallos: 326:4076, del 7/10/2003.

87 Tal la objeción que genera la ausencia de motivación de las desestimaciones bajo el artículo 280 del CPCCN, cuando, al tiempo de emitirse el fallo, se podría publicar, junto con este, el archivo en formato PDF de la decisión del superior tribunal de la causa. Se vuelve sobre ello infra.

88 A modo de ejemplo, Resolución s.n. de la Corte Suprema de Justicia de la Nación, Fallos: 228:44, del 25/02/1954, esp. p. 44.

89 Peyrú, Diego Alberto s/pedido de extradición Embajada de la República de Chile, Fallos: 316:1853, del 27/08/1993. 
judiciales, y en especial la Corte Suprema, ${ }^{90}$ se hallará sujeta a la regla de razonabilidad, límite aplicable a todo control de ejercicio de potestad reglamentaria. En el específico campo de las contrataciones, un reglamento judicial que las regle tiene que asegurar no solo eficacia, sino también eficiencia, conforme modernos criterios de lucha contra la corrupción, con lo que la ineficacia y la ineficiencia constituyen limitaciones. ${ }^{91}$

Finalmente, la costumbre también constituye un límite y, como tal, tiene que poder ser acreditada a los fines de fundar la medida reglamentaria, no bastando a tal fin la mera declaración de que esta recoge la costumbre. ${ }^{92}$ Hay un basamento de repetición o costumbre en la formación de las normas, ${ }^{93}$ que se halla ligada a la reiteración, por un lado, y a la moral, por el otro. De tal suerte, el ejercicio de la potestad reglamentaria no solo hallará los límites ya reseñados de eficacia y de eficiencia, sino también de tenor ético.

90 Se toma la figura de Mulligan y Staszewski (2012, p. 1190).

91 Ver Ley 26097, BO 9/06/2006, artículo 7.I.a. Por otro lado, según la Ley 23853 de autarquía judicial, BO 24/10/1990, artículo 10, "El Poder Ejecutivo nacional juntamente con la Corte Suprema de Justicia de la Nación reglamentará la presente ley en los aspectos concernientes a la administración financiero-presupuestaria, de conformidad con los principios de transparencia en la gestión y uso eficiente de los recursos. Todo ello de conformidad con lo establecido en el artículo $1^{\circ}$ de la ley 24.937 y sus modificatorias".

92 Ver el específico supuesto de la Acordada 4/2007, BO 21/03/2007, del 21/03/2007, motivada en requisitos emergentes de "reiterados y conocidos precedentes". Sin embargo, sus innovaciones en materia de tope expresado y en cantidad de páginas no hallan fundamento expreso alguno en la motivación de esa acordada o en otras fuentes accesibles emanadas de la Corte Suprema. Ese tope, expresado en cantidad de páginas, además no se corresponde con la Regla 33.1.(d.) de la Suprema Corte de los Estados Unidos, que establece la extensión del libelo no en cantidad de páginas, sino en cantidad de palabras. Las reglas de la Suprema Corte estadounidense, vigentes desde julio de 2019, pueden verse en: https://www.supremecourt.gov/ctrules/2019RulesoftheCourt.pdf.

Por ejemplo, un pedido de certiorari de la Regla 14 tiene, como tope, 9000 palabras. Según la Regla 11.1.(h.), basta, a los fines de la acreditación de la cantidad de palabras, la declaración jurada del letrado interviniente basada en el informe que el procesador de palabras brinda: un documento preparado bajo la Regla 33.1. debe hallarse acompañado por un certificado, firmado por el abogado, la parte no asistida por abogado, o quien prepare el documento, declarando que el escrito cumple con el límite de palabras. La persona que prepare el certificado puede sustentarse en el conteo de palabras del procesador de palabras empleado para preparar el documento. El procesador de palabras tiene que ser fijado para incluir notas al pie en el conteo de palabras. El certificado tiene que establecer la cantidad de palabras del documento. El certificado acompañará al documento cuando este sea presentando ante el Clerk para ser ingresado y será independiente de aquel. ("A document prepared under Rule 33.1 must be accompanied by a certificate signed by the attorney, the unrepresented party, or the preparer of the document stating that the brief complies with the word limitations. The person preparing the certificate may rely on the word count of the word-processing system used to prepare the document. The word-processing system must be set to include footnotes in the word count. The certificate must state the number of words in the document. The certificate shall accompany the document when it is presented to the Clerk for fling and shall be separate from it").

93 Ampliar en Ullmann-Margalit (1977, p. 83). Sobre el derecho judicialista, que consiste en un conjunto de costumbres normativas, ver, con provecho, Rivas (2019, pp. 113-114). 
Hay, por cierto, un área "intersticial" de ejercicio de potestad reglamentaria que podría ser pasible de debate en cuanto a su origen en el artículo 113 de la $\mathrm{CN}$, o en los artículos 75, inciso 20 y 116 y 117 de la $\mathrm{CN}$, con lo que podría poner en juego los límites ya repasados sobre potestad reglamentaria autónoma basada en poderes inherentes y el rol de la Corte Suprema como guardián último de la Constitución, por un lado, o bien los límites precedentemente señalados.

\section{El aporte de la experiencia estadounidense de cara a la potestad reglamentaria de la Corte Suprema argentina}

¿Cómo pueden los párrafos precedentes contribuir a una adecuada visualización del Decreto 635/2020?94

En primer lugar, adviértase que dicho decreto se halla enderezado a la producción de una "descripción valorativa" que señale, en especial, "problemas que se observan para el correcto funcionamiento de la Corte Suprema de Justicia de la Nación”. Pues bien, el Alto Tribunal ya ha demostrado habilidad para detectar problemas y proveer soluciones, y eso es lo que hizo al dictar las Acordadas 32/2014 y 12/2016 de procesos colectivos con invocación de la ausencia de ley reguladora de estos. ${ }^{95}$ También desplegó, antes que otros poderes del Estado, poder regulatorio en cuanto a los déficits de transparencia en la gestión y los solucionó mediante la sanción de pluralidad de acordadas que incluyen: las audiencias públicas para ciertas causas; ${ }^{96}$ la bilateralidad en las entrevistas; $;{ }^{97}$ la institución de los amicus curiae; ${ }^{98}$ el régimen del pedido de autos principales y pase a la Procuración General de la Nación; ${ }^{99}$ la divulgación de los fallos de la Corte Suprema; ${ }^{100}$ la publicidad de la circulación de expedientes; ${ }^{101}$ la publicidad, en la página web de la Corte Suprema, de la lista de causas con posterioridad

94 Decreto 635/2020, BO 30/07/2020, creación del Consejo Consultivo para el Fortalecimiento del Poder Judical y del Ministerio Público.

95 Ampliar en Sagüés (2019, p. 400), quien señala que la Corte Suprema "había detectado en el Congreso una especie de inconstitucionalidad por omisión, al no regular los procesos colectivos y la class action encapsulados en el segundo párrafo del artículo 43 de la CN [...]”.

96 Acordada 30/2007.

97 Acordada $7 / 2004$.

98 Acordada 28/2004.

99 Resolución 217/2004, Fallos: 327:1378, del 24/02/2004.

100 Acordada 37/2003, del 18/12/2003.

101 Acordada 35/2003, del 11/12/2003. 
a la celebración de cada acuerdo; ${ }^{102}$ la asignación de trámite diferenciado para causas que involucren materias de trascendencia institucional, ${ }^{103}$ tal que se debe "fijar la fecha del acuerdo en la que el asunto será considerado por el Tribunal" ${ }^{104}$ Asimismo, se ha comenzado a posibilitar -varios clics mediante- el acceso a información relativa al cúmulo de sentencias descalificadas por arbitrariedad, ${ }^{105}$ con relación al tribunal del cual hayan emanado, lo que es un incentivo válido para el control y la prevención de esa clase de sentencias. ${ }^{106}$

También ha detectado la Corte Suprema, como vimos antes, problemas propios del manejo de recursos extraordinarios y de queja cuando se carece de algún criterio de normalización o estandardización de dichas presentaciones. Ahora, la respuesta brindada mediante la Acordada 4/2007, como toda experiencia reguladora que en parte recoge costumbre y en parte innova, ${ }^{107}$ es perfectible y requiere de revisiones. Consideremos, solamente, que la Suprema Corte estadounidense cuenta con sus propias Rules (que incluyen las formalidades de los pedidos de certiorari), pero esas reglas son objeto de permanente revisión y en promedio han sido modificadas cada cuatro años desde $1803,{ }^{108} \mathrm{y}$ lo mismo tendríamos que esperar con relación a la precitada Acordada 4. Ello, en especial, de cara a objeciones relativas a la forma de establecimiento del tope en la extensión de los recursos en ella reglados. ${ }^{109} \mathrm{Y}$, en general, ante la innega-

102 Resolución 642, del 17/04/2004.

103 Acordada 36/2003, del 18/12/2003.

104 Reglamento para la Justicia Nacional, artículo 84

105 Resolución 801/2004, Fallos: 327:3004, del 13/05/2004, modificada por Acordada 51/2009, del 29/12/2009, artículo 8 (esta última, a su vez, fue modificada por la Acordada 31/2014, del 30/09/2014, y por la Acordada 4/2015, del 10/03/2015, pero ellas no alteraron el objetivo de transparencia prefijado).

106 Acerca de todas las soluciones brindadas mediante las acordadas y resoluciones enumeradas, ver, con provecho, Hockl y Duarte (2006, pp. 148-174).

107 Cfr. voto del juez Fayt en la Acordada 4/2007: "Que el ordenamiento aprobado en el presente acuerdo constituye un fiel catálogo de los diversos requisitos que conocidos y reiterados precedentes del Tribunal vienen exigiendo con respecto a los escritos de interposición del recurso extraordinario, y de la presentación directa ante la denegación de aquél [...]”, aunque, en rigor, hay recaudos que no tenían antecedente, cual el límite de carillas.

108 La última versión de dichas Reglas rige desde el 1 de julio de 2019. Pero tengamos en cuenta la esencial modificabilidad de estas: la primera versión, de 1803, comprendía 18 reglas, que ocupaban tres carillas del United States Reports; a partir de allí, se produjeron, hasta 2019, más de medio centenar de modificaciones; cfr. Suprema Corte de los Estados Unidos (s.f.-a). Hoy, las Rules constituyen un opúsculo de 81 carillas y se las puede consultar en: Suprema Corte de los Estados Unidos (2019).

109 Con todo acierto, han señalado Garay y Schvartzman (2007, p. 920), que: "existe otro tipo de causas que, por la complejidad del tema que se discute, los tropiezos habidos durante su trámite o los años de litigio, no será pasible de ser analizado, resumido y alegado en la extensión requerida, 
ble eficiencia de fijar no un tope de renglones por página (renglones que tienen que ser contados por un operador judicial), sino un tope total de palabras en el documento (como se prevé en esas Rules, y que el procesador de palabras cuenta en forma infalible) o, alternativamente, un sencillo límite de renglones en el documento considerado integralmente, sin la carátula.

Respecto al problemático cúmulo de expedientes que recibe anualmente el máximo Tribunal, el ejercicio de la potestad reglamentaria de la Corte Suprema -dentro de las limitaciones constitucionales, algunas de las cuales se resaltaron en el apartado 2.- podría permitirle centrarse en ser el Tribunal de los más importantes casos constitucionales. Sin apuntar a los guarismos que enfrenta la Suprema Corte estadounidense ${ }^{110}$ y atento al proceso que históricamente ha redundado en la discrecionalización de la jurisdicción de la Corte Suprema argentina ${ }^{111}$-amén de la tendencia a la sobrejudicialización de asuntos o conflictos (Rosatti, 2018)-, ${ }^{112}$ entiendo que el Alto Tribunal argentino bien puede, bajo la Ley 25488 de modificación del CPCCN, ${ }^{113}$ artículo 4, diseñar los medios para alcanzar aquel objetivo. Puede ilustrarse lo dicho con el supuesto de los planteos de arbitrariedad de sentencias y, en general, con las decisiones que son apeladas ante la Corte Suprema. Veamos.

Respecto a la administración judicial del cúmulo de planteos de sentencia arbitraria, vale tener presente propuestas concretas ya sugeridas por la doctrina

todo ello dentro del exiguo plazo de diez días”. Esta opinión es recogida tanto en Sagüés (2018, p. 298), advirtiendo que podría llegar a haber lesión al derecho de defensa en juicio y un supuesto de inconstitucionalidad relativa, como en Gozaini (2010, pp. 898-911).

110 Estados Unidos tiene una población aproximada de 328 millones de habitantes; Argentina tiene una población aproximada de 44 millones de habitantes. La Suprema Corte estadounidense recibe entre 7000 y 8000 nuevos casos por año, de los cuales ameritan revisión plenaria, con alegatos orales de los letrados, alrededor de 80, y la Corte suele disponer de 100 o más casos por año sin revisión plenaria, cfr. Suprema Corte de los Estados Unidos (s.f.-b). La Corte Suprema argentina, en cambio, recibió en 2018 no 1000 (que sería lo esperable, proporcionalmente), sino más de 27000 causas (incluyendo 15534 previsionales), cfr. Corte Suprema de Justicia de la Nación (2020).

111 Cfr. fallos citados en Bianchi (1997, pp. 923-941).

112 "La creciente litigiosidad, o -para decirlo de un modo más técnico- la creciente judicialización de los conflictos, es el reconocimiento de la incapacidad para resolver un problema antes de pisar un tribunal de justicia. Y lamentablemente (y tal vez paradójicamente) es un problema que no ha podido resolver la vigencia continuada del sistema democrático, pues los números de causas ingresadas y resueltas se ha incrementado notoriamente desde -cuando menos- 1991 hasta la fecha" (Rosatti, 2018, p. 988). Sobre la sobrejudicialización de asuntos, ver también Rosenkrantz (2018, p. 17): "Por otro lado, sin embargo, en nuestras democracias actuales también hay una tendencia creciente a la judicialización de absolutamente todos los asuntos, incluso de aquellos que dependen de visiones morales, religiosas o políticas".

113 Ley 25488, BO 22/11/2001, modificatoria del CPCCN. 
especializada. ${ }^{114}$ Desde una plataforma diversa, entiendo que la mera posibilidad de escrutinio público puede poseer la virtualidad de desincentivar el dictado de sentencias definitivas arbitrarias, y si bien las decisiones de las cámaras federales son accesibles mediante el Centro de Información Judicial, no ocurre lo mismo con la integralidad de los demás tribunales que son superior tribunal de la causa para la Corte Suprema. ${ }^{115}$ Ello redunda en un parcial acceso, por parte del público, a aquellos decisorios, y, como tarea pendiente, obliga a volver sobre una aguda observación -de permanente vigencia- oportunamente formulada por la doctrina respecto a lo que se espera de esos tribunales y la realidad (Carrió, 1990, p. 23). Para los superiores tribunales remisos en publicar sus decisiones (y en plena era del acceso a la información pública, propia de una república), pueden propiciarse convenios entre dichos tribunales y la Corte Suprema en pos de la obligatoria publicación, bajo la modalidad de acceso abierto, en la página web de aquellos. Ello, con previo cumplimiento de los recaudos habituales respecto a datos no publicables, con disponibilidad de herramientas de búsqueda por palabra libre sin recaudo previo de registración personal o claves y con un mínimo de clics.

En general, más allá de los planteos de arbitrariedad y por razones de transparencia, el Alto Tribunal mismo podría proceder, respecto a todas las decisiones que son apeladas ante sus estrados, a la incorporación de una imagen bajo forma de portable document format de la decisión recurrida, cualquiera haya sido el superior tribunal de la causa. Tal proceder, de otra parte, en el caso de que se resolviera por aplicación del artículo 280 del CPCCN, brindará motivación al fallo respectivo y neutralizará las objeciones que se pudieran haber generado. Y, en general, tal proceder coadyuvará al rol docente del máximo Tribunal.

\section{Conclusión}

Si no fuera por algunos graves fenómenos que nos rodean, resultaría innegable el elevado propósito en torno al Decreto 635/2020 de fortalecimiento del Poder Judicial mediante la tarea de detección de problemas de su funcionamiento en pos de su superación. Es que toda república aspira a una rama judicial fuerte, bien erguida ante los poderes políticos y comprometida con la trascendente

114 Cfr. Carrió (1990, pp. 20-24), expresiones de llamativa actualidad; Garay (2010, pp. 27-39).

115 Si bien hay superiores tribunales provinciales que publican en forma óptima todas sentencias, facilitando la recuperación de documentos, ello dista de ser la regla. Para un informe actualizado a 2015, ver Elena y Ecker (2015). 
labor de sembrar seguridad jurídica y confianza en las instituciones con la consiguiente retroalimentación a nivel nacional e internacional.

Empero, estimo que -al menos en lo que hace a la máxima instancia judicial argentina-, huelgan, a tal fin, las iniciativas legislativas impulsadas desde la rama ejecutiva de gobierno. Es que, en lo que hace a dicha máxima instancia judicial, nadie sabe más del funcionamiento de la Corte Suprema que la Corte Suprema misma.

Así las cosas, y como vimos, ya desde antaño ha puesto en práctica el Alto Tribunal -con verdadera actitud proactiva- las formidables herramientas reglamentarias que posee para autodetectar aquellos aspectos de su quehacer que ameritan enmiendas en pos de una producción jurisdiccional eficaz y eficiente con conciencia ética. Para ello, ya sea por asignación directa de competencia por el Constituyente como por delegación legislativa del Legislador, e incluso en el espacio para la ejecución de las leyes que sanciona este, la potestad reglamentaria que asiste al Tribunal ha demostrado ser clave en la elaboración de autodiagnósticos y adopción de medidas apropiadas. En el ejercicio de tal competencia, resultará esencial el respeto de las limitaciones de fuente constitucional o infraconstitucional, algunas de las cuales fueron puntualizadas en estos párrafos.

\section{Bibliografía}

Badeni, G. (2010). Tratado de Derecho constitucional (3a ed., Tomo III). Buenos Aires: La Ley.

Bianchi, A. B. (1986). Justiciabilidad de las acordadas de la Corte Suprema de Justicia. El Derecho, (119), 181-185.

Bianchi, A. B. (1990). La delegación legislativa. Buenos Aires: Ábaco.

Bianchi, A. B. (1997). ¿Ha llegado la Corte Suprema al final de su lucha por una jurisdicción discrecional? (Perspectivas actuales y futuras del recurso extraordinario). El Derecho, (172), 923-941.

Bianchi, A. B. (2014). La Corte bajo la presidencia de Raúl Alfonsín. En Santiago, A. (h) (Dir.), Historia de la Corte Suprema argentina (Tomo III, pp. 1163-1293). Madrid/Barcelona/Buenos Aires/San Pablo: Marcial Pons.

Bidart Campos, G. (1993). Tratado elemental de Derecho constitucional Argentino (Tomo II). Buenos Aires: Ediar.

Bidart Campos, G. (1997). Manual de la Constitución reformada (Tomo III). Buenos Aires: Ediar. Bielsa, R. (1959). Derecho constitucional. Buenos Aires: Depalma.

Cabral, J. E. (1986). Inconstitucionalidad de la Acordada 43/1995 de la CSJN. El Derecho, (119), 184-185. 
Carrió, G. R. (1990). Sobre la competencia de la Suprema Corte argentina y su necesaria y urgente modificación. Revista del Centro de Estudios Constitucionales, (5), 9-43.

Cassagne, J. C. (2018). Curso de Derecho administrativo (12 a ed., Tomo I). Buenos Aires: La Ley.

Cassagne, J. C. (2020). Derecho administrativo y Derecho público general. Montevideo/Buenos Aires: BdeF.

Castro Videla, D. y Maqueda Fourcade, C. S. (2018). La delegación legislativa y el Estado regulatorio. Buenos Aires: Ábaco.

Corte Suprema de Justicia de la Nación. (2020). Datos estadísticos. Sentencias de la Corte Suprema. Año 2018. Cantidad de causas ingresadas por materia. https://www.csjn.gov.ar/datos-estadisticos/graficos-2018.

Elena, S. y Ecker, G. (2015). Indice de acceso a la información judicial de las provincias argentinas (edición 2015) (Documento de Políticas Públicas, Análisis No 152). Buenos Aires: CIPPEC. https://www.cippec.org/wp-content/uploads/2017/03/1203.pdf.

Garay, A. F. (2010). El recurso extraordinario por sentencia arbitraria. Propuesta para un manejo más ágil. Suplemento Extraordinario Constitucional - 75 aniversario. Buenos Aires: La Ley.

Garay, A. F. (2015). La doctrina del precedente y la seguridad juridica (Ponencias generales, procesal constitucional). XXVIII Congreso Nacional de Derecho Procesal, Buenos Aires. https:// www.aadproc.org.ar/pdfs/biblioteca_virtual/Congreso_2015/Ponencias\%20Generales/ Procesal\%20Constitucional/GARAY\%2C\%20Alberto\%20F..pdf.

Garay, A. F. y Schvartzman, S. (2007). El recurso extraordinario y su reglamentación por la acordada 4/2007. J.A., 2007-II, 918-926.

Gelli, M. A. (2008). Constitución de la Nación argentina. Comentada y concordada (4ª ed., Tomo II). Buenos Aires: La Ley.

Gordillo, A. (2009). Tratado de Derecho administrativo (Tomo I). Buenos Aires: FDA.

Gozaini, O. A. (2010). La trascendencia en el recurso extraordinario frente a la Acordada 4/200. La Ley, 2010-C, 898-911.

Hockl, M. C. y Duarte, D. (2006). Competencias y atribuciones de la Corte Suprema de Justicia de la Nación. Buenos Aires: Legis.

Luqui, R. (2005). Revisión judicial de la actividad administrativa (Tomo I). Buenos Aires, Astrea.

Marienhoff, M. S. (1990). Tratado de Derecho administrativo (4⿳a ed., Tomo II). Buenos Aires: Abeledo Perrot.

Meador, D. J. (1995). Inherent Judicial Authority in the Conduct of Civil Litigation. Texas Law Review, 73, 1805-1820.

Mulligan, L. N. y Staszewski, G. (2012). The Supreme Court's Regulation of Civil Procedure: Lessons from Administrative law. UCLA Law Review, 50, 1188-1251.

Oyhanarte, M. (2015). Public Law Litigation in the U.S. and in Argentina: Lessons from a Comparative Study. Georgia Journal of International and Comparative Law, 43(2), 451-506.

Rivas, P. (2019). En los márgenes del Derecho y el poder. Valencia: Tirant.

Rosatti, H. D. (2018). La Corte Suprema: entre Escila y Caribdis. La Ley, 2018-B, 986-989.

Rosenkrantz, C. F. (2018). Los jueces frente al desarrollo. Conferencia Judicial de las Cortes Supremas del G-20, octubre 2018. https://observatoriojudicial.org/wp-content/ uploads/2019/06/OJO-Discursos-G20-1-1.pdf. 
Sacristán, E. B. (2016). Amparo colectivo en la Argentina: opt-in, opt-out o tal vez nada. Revista Argentina de Derecho de la Energía, Hidrocarburos y Minería, (11), 199-213.

Sacristán, E. B. (2017). La Corte Suprema como intérprete final y el Consejo de la Magistratura. En Asociación Argentina de Derecho Constitucional, Justicia y transparencia. Justicia y división de poderes. Justicia y federalismo. Justicia y desarrollo humano. XXIII Encuentro de Profesores de Derecho Constitucional (pp. 143-151). Resistencia: ConTexto.

Sáenz, J. I. (2008). La Corte Suprema como tribunal constitucional (Sesión privada del Instituto de Política Constitucional del 4 de junio de 2008). Buenos Aires: Academia Nacional de Ciencias Morales y Políticas. https://www.ancmyp.org.ar/user/files/Saenz-2008.pdf.

Sagüés, N. P. (2018). Compendio de Derecho procesal constitucional. Buenos Aires: Astrea.

Sagüés, N. P. (2019). Reflexiones sobre la delegación legislativa en la Corte Suprema de Justicia de la Nación. En Gelli, M. A. (Dir.), A 25 años de la reforma constitucional de 1994 (pp. 395 400). Buenos Aires: La Ley.

Santiago, A. (h). (2014). La Corte de los nueve (1990-2003). En Santiago, A. (h) (Dir.), Historia de la Corte Suprema argentina (Tomo III, pp. 1195-1676). Madrid/Barcelona/Buenos Aires/ San Pablo: Marcial Pons.

Seco Villalba, J. A. (1943). Fuentes de la Constitución argentina. Buenos Aires: Depalma.

Suprema Corte de los Estados Unidos. (2019). Rules of the Supreme Court of the United States. Adopted April 18, 2019. Effective July 1, 2019. https://www.supremecourt.gov/ctrules/2019RulesoftheCourt.pdf.

Suprema Corte de los Estados Unidos. (2020). Granted and Noted list. October Term 2020. Cases for Argument. https://www.supremecourt.gov/orders/20grantednotedlist.pdf.

Suprema Corte de los Estados Unidos. (s.f.-a). Historical Rules of the Supreme Court. https:// www.supremecourt.gov/ctrules/scannedrules.aspx.

Suprema Corte de los Estados Unidos. (s.f.-b). The Term and Caseload. https://www. supremecourt.gov/about/courtatwork.aspx.

Ullmann-Margalit, E. (1977). The Emergence of Norms. Oxford: Oxford University Press.

Whittington, K. E. y Iuliano, J. (2017). The Myth of the Nondelegation Doctrine. University of Pennsylvania Law Review, 165, 379-431. 